Acta Regionalia et Environmentalica 1

Nitra, Slovaca Universitas Agriculturae Nitriae, 2015, pp. 1-5

\title{
FAST-GROWING ENERGY CROPS GROWN IN CONDITIONS OF SLOVAKIA IN THE CONTEXT OF THE EU ENERGY POLICY
}

\author{
Zuzana JUREKOVÁ*, Marián KOTRLA, Martin PRČÍK, Martin HAUPTVOGL, Žaneta PAUKOVÁ \\ Slovak University of Agriculture in Nitra, Slovak Republic
}

\begin{abstract}
The energy-efficient low-carbon EU economy (known as the 20-20-20) sets fundamental objectives in reducing greenhouse gas emissions (20\%), increasing the share of renewable energy sources (20\%) and saving primary energy consumption (20\%). The objectives are incorporated in the National Renewable Energy Action Plans (NREAPs). Slovakia has to increase the share of renewable energy sources (RES) by $14 \%$ in its energy mix by 2020 . Currently, the most widely used RES are water and solar energy, biomass and biogas. Our country has suitable ecological conditions for growing the so called energy crops in lowland and upland areas. So far, however, there is a lack of science-based information on the potential production of biomass in different soil-ecological and climatic conditions of the Slovak Republic. Our experimental research is focused on quantification of biomass production of various willow (genus Salix), poplar (genus Populus) and silvergrass (Miscanthus sinensis) varieties grown in ecological conditions of southern Slovakia. We evaluated the biomass production of the studied crops. The results were evaluated in terms of the EU call (2013): to obtain more energy while reducing inputs and negative environmental impacts.
\end{abstract}

Keywords: energy crop, Salix, Populus, Miscanthus, biomass production, EU energy policy

The EU energy program by 2050 is based on the use of renewable energy sources. Among the renewable sources, bioenergy represents a high proportion. The term means energetic use of any kind of biomass to produce heat, electricity or transport fuels. According to the above mentioned energy program, bioenergy should be obtained through a more efficient use of resources, reduction of energy inputs for their production, and reduction of negative environmental impacts. In Slovakia, the renewable energy sources were used at a limited basis in recent decades. The EU Member States committed to cover $20 \%$ of the energy consumption from renewable sources by 2020 . The share of renewable energy on gross final energy consumption in Slovakia increased from $6.7 \%$ in 2004 to $9.7 \%$ in 2011 . The 2020 target for Slovakia included in National Renewable Energy Action Plan is 14\% (EUROSTAT, 2013).

Biomass is considered to have the greatest potential from the renewables, particularly agricultural biomass of plants grown on arable lands for the energy purposes (agricultural crops, fast-growing trees, plants and grasses grown on agricultural land, freshwater cyanobacteria and algae and other plants). According to Jureková et al. (2011) and Demo et al. (2013a), Slovakia has a potential and suitable climate condition to grow fast-growing trees (Salix sp., Populus sp. and Robinia sp.) and fast-growing plants (Miscanthus, Panicum and Sorghum) (Jureková et al., 2012; Porvaz and Tóth 2013).

Cultivation of energy crops requires changes in structure of the arable land. In this sense, there is a lack of statistical data on areas of agricultural land used for growing fast- growing trees and plants. The paper gives an overview of the current state of the existing data (the Statistical Office of the Slovak Republic (SO SR) (2013) and the Soil Science and Conservation Research Institute of the Slovak Republic (SSCRI SR) (2014)). Our departments have focused on research of fast-growing trees and plants since the last decade. The research has been aimed at selecting species and varieties with optimum characteristics and production potential. The paper summarizes these results, too.

\section{Material and methods}

The maps representing areas of individual types of land use were created in Arcview 3.2 software based on data obtained from SO SR (2013) and SSCRI SR (2014).

The research of energy crops took place in the field base in Kolínany. The basic pedological data are provided by Jureková et al. (2013) and Demo et al. (2013a and 2013b). Selected climate data are shown in Figure 1 and Figure 2.

Average monthly temperatures were monitored in the period of 2009 - 2013 (Figure 1). Total average annual temperature values ranged from 9.9 to $11.3{ }^{\circ} \mathrm{C}$. Larger differences were observed in precipitation (Figure 2). The highest amount of total rainfall was recorded in 2010 ( $860.2 \mathrm{~mm}$ ). In terms of the distribution, the largest monthly rainfall was in May and June 2010. Other years have been relatively dry. In 2011, the annual precipitation was $341.9 \mathrm{~mm}$ and $449.0 \mathrm{~mm}$ in 2012. 


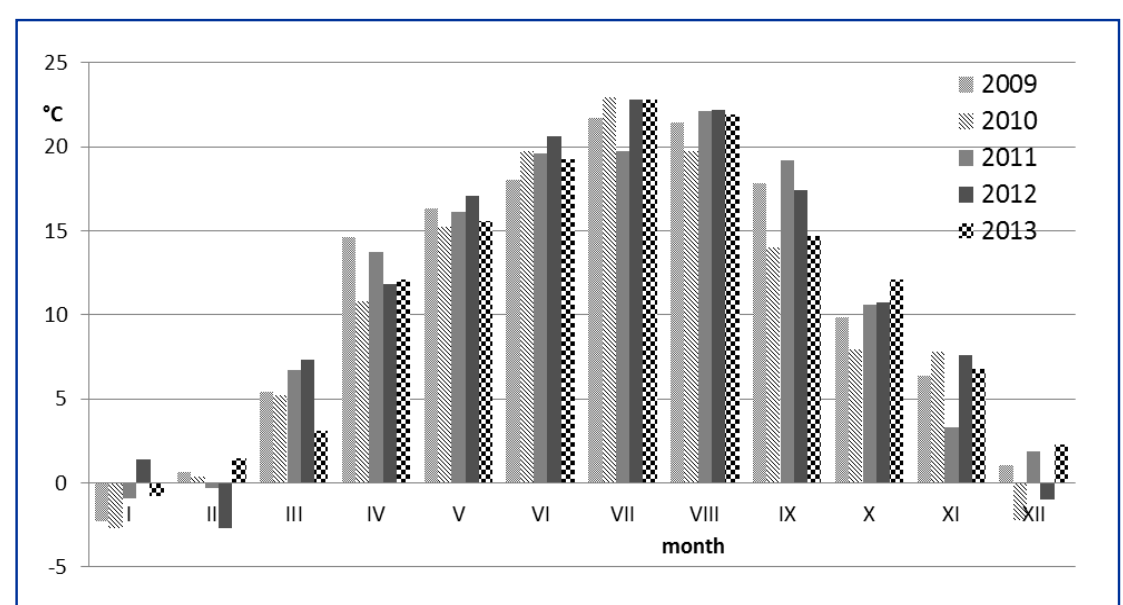

Figure 1 Mean daily temperatures in 2009-2013 measured by the meteorological station Nitra - Vel'ké Janíkovce

Source: SHMI, 2014

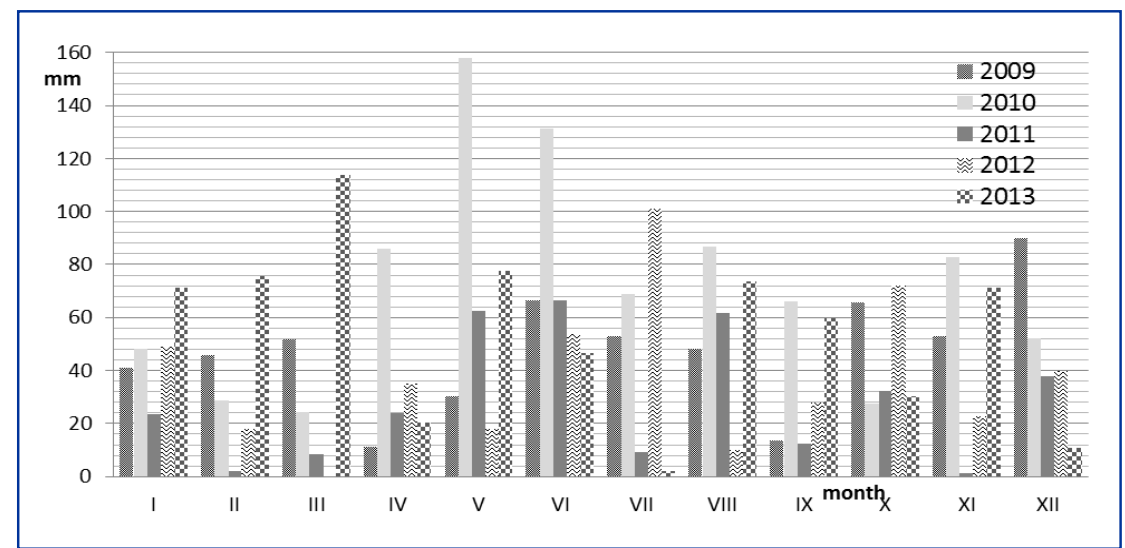

Figure 2 Total precipitation in 2009 - 2013 measured by the meteorological station Nitra - Vel'ké Janíkovce

Source: SHMI, 2014

There were four varieties of Populus spp. (Populus $\times$ canescens) from Italian breeding program (AF-2, Monviso, Pegaso, and Sirio), and five varieties of Salix spp. from Swedish breeding program (Tora, Tordis, Sven, Inger and Gudrun) included in the research.

The planting density of the poplar and willow stands is described in Demo et al. (2013a and 2013b). Individual plants of the five Swedish willow varieties were weighed at the end of the growing season of the fourth year (2010) of the first harvest cycle (3-yearold shoots). The measurements were taken on the site (Hauptvogl, 2011).

The stand of two Miscanthus genotypes: Miscanthus $\times$ giganteus GREEF et DEU and Miscanthus sinensis (Tatai), was established in 2010. The planting density and technology of cultivation is described in Jureková et al. (2012, 2013). Dry above-ground phytomass of individual Miscanthus
United Kingdom, Lithuania and Hungary. In Slovakia, the available arable land for dedicated bioenergy crop cultivation is expected to rise from about $81,000 \mathrm{ha}$ in 2010 to 213,000 ha in 2030 (EEA, 2006).

Fast-growing trees, mainly willows and poplars, as well as energy grasses should play an important role in Slovak renewable energy policy, due to the fact that they are suitable to our agro-ecological and economic conditions. The most suitable ecological conditions can be found in lowlands and highlands located in warmer climate conditions and rather humid soils (SSCRI, 2014). According to SO SR (2013), fast-growing trees currently cover about 676.01 hectares in Slovakia. However, the data are not very reliable and more detailed investigation should be made.

The land that is used for energy cropping is a natural resource, comprising of soil, minerals, water and biota. It plays an important role in delivering valuable ecosystem services, such as supporting the cultivation of biomass for food, energy and other products, and regulating environment (EEA 2013).

Slovak legislation set the condition for cultivation of fast-growing plants on agricultural land. The plantation can be established on soil that is classified in $5-9$ quality category indicated by BPEJ code (number 1 represents the highest quality soil, number 9 the lowest); contaminated soil; soil classified in 3 or 4 quality category if it is located in floodplain, the soil is waterlogged or exposed to wind erosion (Act No 34/2014 Coll.).

Other agricultural lands that are potentially suitable for fast-growing trees include fallow lands and unused agricultural soils. The area of the fallow land in Slovakia is about $13,312.51$ ha and the unused agricultural soils represent 15,575.85 ha (SO SR, 2013). The highest share of both fallow and unused agricultural areas can be found in the Banská Bystrica Region (Figure 3 and Figure 4).

Sensitive areas (contaminated soils) are suitable for fast-growing plants, due to the fact that they are excluded from food production. The sensitive areas of Slovakia are located in the territory of Upper Nitra, Žilina, Ružomberok, Banská Bystrica, Žiar, Jelšava and Hačava (Figure 5). 


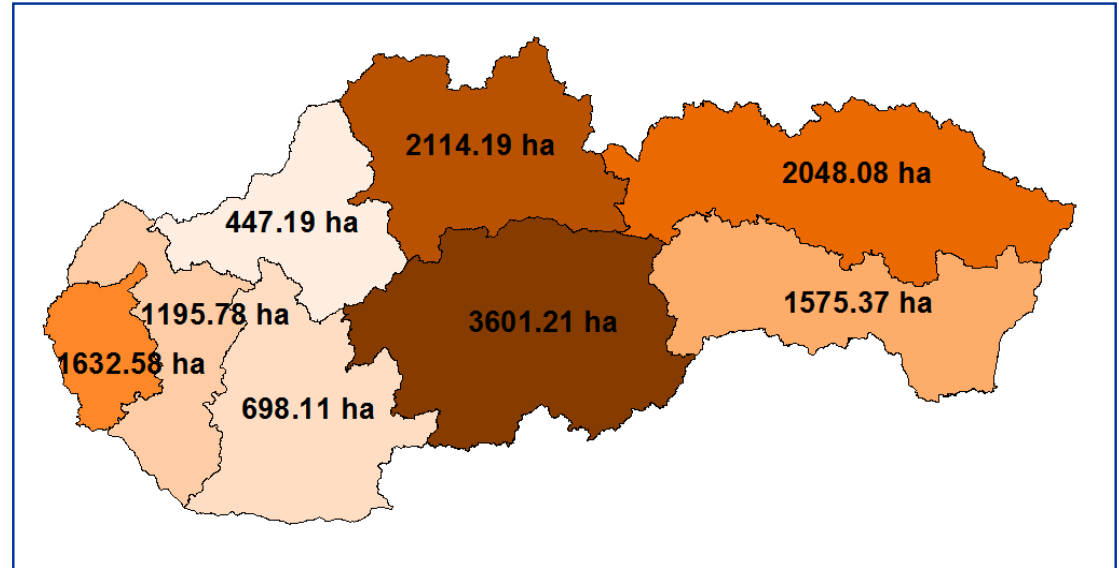

Figure 3 Area of fallow land in Slovak regions Source: based on SO SR, 2013

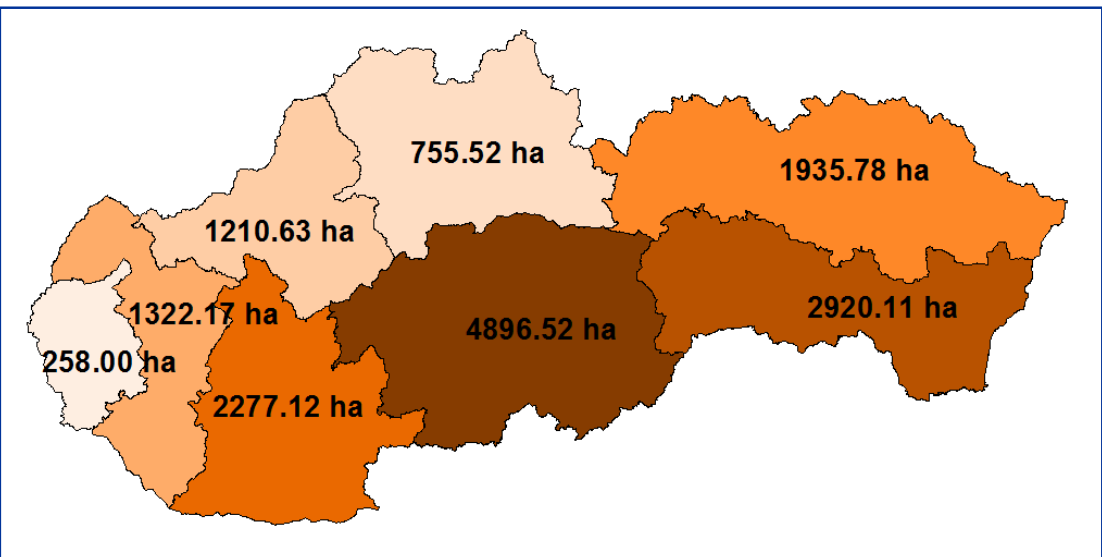

Figure 4 Area of unused agricultural soils in Slovak regions Source: based on SO SR, 2013

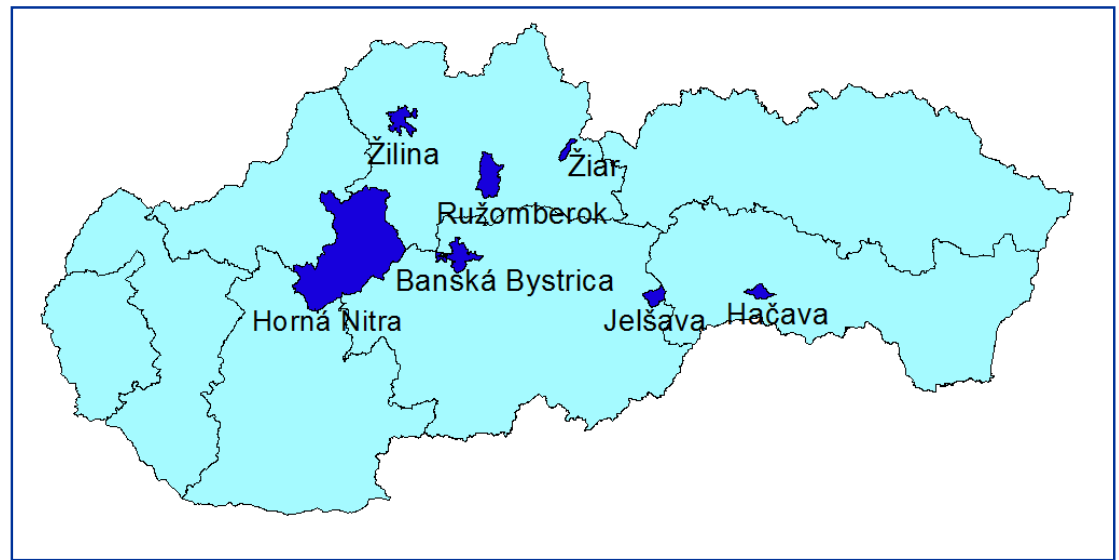

Figure 5 Location of sensitive areas in Slovakia Source: based on VÚPOP, 2014

The highest biomass production potential in Central and Eastern Europe is in countries with the biggest land areas, notably Poland and Romania (van Dam et al., 2007).

A study of potential biomass production of Salix, Populus and Miscanthus in 10 eastern European countries revealed that the highest Salix and Populus potential yields are in the Czech Republic (35.7 $\mathrm{t} \mathrm{ha}^{-1}$ ), and from the former Soviet Union countries in Georgia (38.1 $\mathrm{t} \mathrm{ha}^{-1}$ ). The highest potential yields of Miscanthus were determined in Slovenia $\left(27.5 \mathrm{t} \mathrm{ha}^{-1}\right)$ (Fischer et al, 2005).
Research on fast-growing plants does not have a long tradition in Slovakia compared to the neighbouring countries. The research on Salix began in Krivá, Orava region, in 1994. Our research plantation was established in 2006. We have studied biomass production of five Swedish willow varieties in the fourth growing seasons (2010).

The weight of the fresh matter of the individual willow varieties varied from $12.43 \mathrm{~kg}$ (Tora) to $9.90 \mathrm{~kg}$ (Gudrun). The highest potential yield (survival rate $=100 \%$ ) of the dry matter was provided by Tora (66.11 $\mathrm{t} \mathrm{ha}^{-1}$ $\left.3 \mathrm{yrs}^{-1}\right)$. The lowest yield was recorded in Inger (52.53 t ha $\left.{ }^{-1} 3 \mathrm{yrs}^{-1}\right)$. Content of dry matter varied from 48.47 to $51.02 \%$. We observed that even though Gudrun reached the lowest average weight, due to the highest content of dry matter, it provided higher average yield than Tordis and Inger (Table 1). However, there were no significant statistical differences of the weight and the yield among the willow varieties (Table 2).

Trnka (2009) recorded dry matter biomass ranging from 44.0 to 104.0 $\mathrm{t} \mathrm{ha}^{-1}$ in 15 willow clones at the end of the six-year growing cycle in the microregion Bystřice nad Pernštejnem (Czech Republic)

Annual yields of the five Swedish varieties (Sven, Gudrun, Tora, Sherwood and Ulv) studied in the research plantation located in the northern Slovakia varied from 11.1 to $15.2 \mathrm{t} \mathrm{ha}^{-1}$ year ${ }^{-1}$ (Daniel and Medvecký 2010). In contrast, the varieties Sven, Tora, Tordis and Inger grown in 2-year harvest cycle in Hungary under unfavourable site conditions produced 38,6 $\mathrm{t} \mathrm{ha}^{-1}$ of biomass on average (control variant, 2009) (Mikó et al. 2014).

We also studied biomass yield of four poplar varieties (Monviso, Pegaso, AF-2 and Sirio). The stand was established in 2008. The paper provides yields obtained at the end of the fourth growing season (first rotation cycle) in 2012.

The weight of the fresh matter of the studied poplar varieties ranged from $15.83 \mathrm{~kg}$ (AF-2) to $21.16 \mathrm{~kg}$ (Monviso). The average yield of biomass at harvest moisture content (fresh matter) ranged from $140.74 \mathrm{t} \mathrm{ha}^{-1}$ (AF-2) to $188.14 \mathrm{t} \mathrm{ha}^{-1}$ (Monviso). Content of dry matter ranged from 44.76 to $47.91 \%$. Biomass yield of dry weight varied from $67.42 \mathrm{t} \mathrm{ha}^{-1} 3 \mathrm{yrs}^{-1}$ (AF-2) to $87.16 \mathrm{t} \mathrm{ha}^{-1}$ 3 yrs $^{-1}$ (Monviso) (Table 3). 
Table 1 Biomass yield of the studied willow varieties in the fourth growing season (2010)

\begin{tabular}{|c|c|c|c|c|}
\hline Varieties & $\begin{array}{l}\text { Fresh matter yield } \\
\text { in kg plant }{ }^{-1}\end{array}$ & $\begin{array}{l}\text { Fresh matter yield } \\
\text { in } \mathrm{t} \mathrm{ha}^{-1}\end{array}$ & $\begin{array}{l}\text { Dry mater } \\
\text { in } \%\end{array}$ & $\begin{array}{l}\text { Dry matter yield } \\
\text { in } \mathrm{t} \mathrm{ha}^{-1} 3 \mathrm{yrs}^{-1}\end{array}$ \\
\hline Tora & 12.43 & 132.54 & 49.88 & 66.11 \\
\hline Gudrun & 9.90 & 105.57 & 51.02 & 53.86 \\
\hline Tordis & 10.41 & 110.98 & 48.47 & 53.79 \\
\hline Inger & 10.09 & 107.59 & 48.82 & 52.53 \\
\hline Sven & 11.68 & 124.53 & 49.76 & 61.96 \\
\hline
\end{tabular}

Table 2 Single-factor analysis of variance (ANOVA) of the studied growth parameters among individual willow varieties

\begin{tabular}{|l||c|c|c|c|}
\hline Analysed parameter & F & P value & F critical & Significance \\
\hline \hline Weight of the fresh matter & 1.083741 & 0.379511 & 2.641465 & $\mathrm{n}$ \\
\hline Yield of the dry matter & 1.158701 & 0.345649 & 2.641465 & $\mathrm{n}$ \\
\hline
\end{tabular}

Level of significance is defined as: $n$ - non-significant impact, ${ }^{+}$significant impact in $P \leq 0.05,{ }^{++} P \leq 0.01$ and ${ }^{+++} P \leq 0.001$

Table 3 Biomass yield of the studied poplar varieties in the fourth growing season (2012)

\begin{tabular}{|c|c|c|c|c|}
\hline Varieties & $\begin{array}{l}\text { Fresh matter yield } \\
\text { in kg plant }{ }^{-1}\end{array}$ & $\begin{array}{l}\text { Fresh matter yield } \\
\text { in } \mathrm{t} \mathrm{ha}^{-1}\end{array}$ & $\begin{array}{l}\text { Dry mater } \\
\text { in } \%\end{array}$ & $\begin{array}{c}\text { Dry matter yield } \\
\text { in t ha-1 } 3 \text { yrs }^{-1}\end{array}$ \\
\hline Monviso & 21.16 & 188.14 & 46.33 & 87.16 \\
\hline Pegaso & 18.83 & 167.40 & 45.94 & 76.90 \\
\hline AF-2 & 15.83 & 140.74 & 47.91 & 67.42 \\
\hline Sirio & 19.76 & 175.70 & 44.76 & 78.64 \\
\hline
\end{tabular}

Table 4 Single-factor analysis of variance (ANOVA) of the biomass yields among individual poplar varieties

\begin{tabular}{|l||c|c|c|c|}
\hline Analysed parameter & F & P-value & F critical & Significance \\
\hline \hline Yield of the dry matter & 1.622233 & 0.223663 & 3.238872 & $\mathrm{n}$ \\
\hline
\end{tabular}

Level of significance is defined as: $n$ - non-significant impact, ${ }^{+}$significant impact in $P \leq 0.05,{ }^{++} P \leq 0.01$ and ${ }^{+++} P \leq 0.001$

Table 5 Yield of the studied miscanthus genotypes recorded in the research base in Kolínany in the period of 2010-2013

\begin{tabular}{|l||c|c|c|c|}
\hline \multicolumn{1}{|l||}{ Genotypes } & \multicolumn{4}{|c|}{ Dry matter yield of Miscanthus in t ha-1 year $^{-1}$} \\
\cline { 2 - 5 } & $\mathbf{2 0 1 0}$ & $\mathbf{2 0 1 1}$ & $\mathbf{2 0 1 2}$ & $\mathbf{2 0 1 3}$ \\
\hline \hline Miscanthus $\times$ giganteus GREEF et DEU & 11.10 & 18.10 & 27.10 & 30.30 \\
\hline Miscanthus sinensis (Tatai) & 10.80 & 15.21 & 22.63 & 24.10 \\
\hline
\end{tabular}

Table 6 Single-factor analysis of variance (ANOVA) of the biomass yields between the miscanthus genotypes in individual years (2010-2013) and between genotypes in each experimental year

\begin{tabular}{|l||c|c|c|c|}
\hline Analysed parameter & F & P-value & F critical & Significance \\
\hline \hline Miscanthus $\times$ giganteus GREEF et DEU - Years & 494.2242 & $3.04 \mathrm{E}-40$ & 2.769431 & +++ \\
\hline Miscanthus sinensis (Tatai) - Years & 391.1096 & $1.62 \mathrm{E}-37$ & 2.769431 & +++ \\
\hline Genotypes and Years & 393.7085 & $9.37 \mathrm{E}-76$ & 2.092381 & +++ \\
\hline
\end{tabular}

Level of significance is defined as: $n$ - non-significant impact, ${ }^{+}$significant impact in $P \leq 0.05,{ }^{++} P \leq 0.01$ and ${ }^{+++} P \leq 0.001$

Trnka (2009) recorded, in eight poplar clones of a six-year-old stand in the microregion of Bystřice nad Pernštejnem (Czech Republic), average biomass yield of dry matter ranging from $70.0 \mathrm{t} \mathrm{ha}^{-1}$ to $127.0 \mathrm{t} \mathrm{ha}^{-1}$. A two-yearold poplar stand grown in the soil-ecological conditions of Northwest Hungary (Kapuvár - Kistölgyfapuszta) provided biomass yield of dry matter that varied from $18.06 \mathrm{t} \mathrm{ha}^{-1}$ to 35.40 t ha $^{-1}$ (Németh, 2010).
The economic threshold for the cultivation of willow and poplar, according to Lindegaard et al. (2001) is 10-12 t ha-1 year $^{-1}$ of dry matter. In our research, all monitored willow and poplar varieties exceeded the economic threshold.

There were no significant differences in biomass yield among the poplar varieties (Table 4).

The total production of the aboveground biomass for the first four years of the two studied genotypes of 
Miscanthus reached $86.60 \mathrm{t} \mathrm{ha}^{-1} 4 \mathrm{yrs}^{-1}$ and $72.74 \mathrm{t} \mathrm{ha}^{-1} 4 \mathrm{yrs}^{-1}$ in Miscanthus $\times$ giganteus GREEF et DEU and Miscanthus sinensis (Tatai), respectively (Table 5). The difference of the obtained yield between the genotypes represents $12.6 \%$ that is $11.17 \mathrm{t} \mathrm{ha}^{-1}$.

The average weight of dry matter of the studied Miscanthus genotypes has been increasing since 2010. There were statistically highly significant differences between the genotypes in the observed years (Table 5). Our findings were confirmed by Porvaz and Tóth (2013), who studied biomass production of Miscanthus in Eastern Slovak Lowland (Eastern Slovakia).

\section{Conclusion}

There are suitable conditions for growing energy crops in Slovakia. Currently, there are about 676.01 hectares of fastgrowing trees in Slovakia. The area of these crops, as well as energy perennial grasses such as Miscanthus should increase in the coming years. There is potential for establishment of energy plantations on fallow, unused and contaminated agricultural soil. Our research focused on five Swedish willow varieties, four poplar varieties and two genotypes of Miscanthus. The results confirmed that the studied willow varieties, grown in the first rotation cycle (2007-2011), performed their production potential differentially. The differences of the biomass yield among the varieties were not statistically significant. The biomass yield of the willow varieties ranged from 52.53 to $66.11 \mathrm{t} \mathrm{ha}^{-1} 3 \mathrm{yrs}^{-1}$ of dry matter. The results of the poplar varieties studied in the first rotation cycle (2008-2012) confirmed the ability of intensive biomass production. The poplar varieties provided biomass yield of dry matter ranging from 67.42 to $87.16 \mathrm{t} \mathrm{ha}^{-1} 3 \mathrm{yrs}^{-1}$.The differences among individual varieties were not statistically significant. The Miscanthus genotypes were studied during 2010-2013. The biomass yield has been increasing each year. The total biomass yield of the genotypes reached $86.60 \mathrm{t} \mathrm{ha}^{-1}$ $4 \mathrm{yrs}^{-1}$ and $72.74 \mathrm{t} \mathrm{ha}^{-1} 4 \mathrm{yrs}^{-1}$ in Miscanthus $\times$ giganteus GREEF et DEU and Miscanthus sinensis (Tatai), respectively. There were statistically highly significant differences between the two genotypes during the observed years.

Abiotic factors during the studied period did not limit growth, life cycle and/or the amount of the biomass production.

\section{Acknowledgment}

This paper was supported by the Slovak Grant Agency for Sciences /VEGA/ Grant No.1/1220 and by the AgroBioTech ITMS 26220220180.

\section{References}

Act No 34/2014 Coll. amending Act No 220/2004 Coll. on the protection and use of agricultural land and on amending Act No 245/2003 Coll. on integrated prevention and control of environmental pollution amending and supplementing certain acts.

DANIEL, J. - MEDVECKÝ, M. 2010. Vŕba košikárska (Salix viminalis) produkčný potenciál nových odrôd. In Pestovatel'ské technológie a ich význam pre prax : zborník príspevkov z I. vedeckej konferencie. Piešt’any : Centrum výskumu rastlinnej výroby Pieštany, 2010. s. 121-122. DEMO, M. - FAZEKAS, A. - HAUPTVOGL, M. - SKLADAN, B. TÓTHOVÁ, M. 2013a. Produkčný a energetický potenciál švédskych odrôd rýchlorastúcej dreviny rodu Salix pestovanej v suchších pôdno-klimatických podmienkach juhozápadného Slovenska. Nitra : SPU, 2013. 110 s. ISBN 978-80-552-1064-3.

DEMO, M. - PRČÍK, M. - TÓTHOVÁ, D. - HÚSKA, D. 2013b. Production and energy potential of different hybrids of poplar in the soil and climatic conditions of south-western Slovakia. In Wood Research, vol. 58, 2013, no. 3, pp. 439-450.

EEA. 2006. How much bioenergy can Europe produce without harming the environment? EEA Report No 7/2006.

EEA. 2013. EU bioenergy potential from a resource-efficiency perspective. EEA Report No 6/2013. ISSN 1725-9177.

EUROSTAT. 2013. Renewable energy. Share of renewable energy up to $13 \%$ of energy consumption in the EU-27 in 2011. [Retrieved 2014-11-27]. Retrieved from: http://epp.eurostat.ec.europa.eu/ cache/ITY_PUBLIC/8-26042013-AP/EN/8-26042013-AP-EN.PDF.

FISCHER, G. - PRIELER, S. - van VELTHUIZEN, H. 2005. Biomass potentials of miscanthus, willow and poplar: results and policy implications for Eastern Europe, Northern and Central Asia. In Biomass and Bioenergy, vol. 28, 2005, no. 2, pp. 119-132. ISSN 0961-9534.

HAUPTVOGL, M. 2011. Vplyv pôdno-klimatických a hydrologických podmienok juhozápadného Slovenska na vybrané produkčné ukazovatele rýchlorastúcej energetickej dreviny rodu Salix): PhD. thesis. Nitra : SPU, 2011.119 s.

JUREKOVÁ, Z. - DRAŽIČ, G. - KOTRLA, M. - MARIŠOVÁ, E. MILOVANOVIČ, J. - TÓTHOVÁ, M. - KONČEKOVÁ, L. 2011. Biological factors influencing the growth and biomass production of willows planted in Southern Slovakia 2011. In Acta regionalia et environmentalica, vol. 8, 2011, no. 2, pp. 47-5. ISSN 1336-5452.

JUREKOVÁ, Z. - KOTRLA, M. - PAUKOVÁ, Ź. - PRČÍK, M. 2012. Rast a tvorba biomasy genotypov Miscanthus $v$ podmienkach juhozápadného Slovenska. In Acta regionalia et environmentalica, roč. 9, 2012, č. 2, s. 29-34. ISSN 1336-5452.

JUREKOVÁ, Z. - KOTRLA, M. - PAUKOVÁ, Ž. 2013. Life cycle of Miscanthus $\times$ giganteus (Greef et Deu) grown in Southwestern Slovakia. In Acta regionalia et environmentalica, vol. 10, 2013, no. 2, pp. 40-43. ISSN 1336-5452.

LINDEGAARD, K. N. - PARFITT, R. I. - DONALDSON, G. -HUNTER, T. 2001. Comparative trials of elite Swedish and UK biomass willow varieties. In Aspects of Applied Biolog, vol. 65, 2001, pp. 183-192.

MIKÓ, P. - KOVÁCS, G. P. - ALEXA, L. - BALLA, I. - PÓTI, P. GYURICZA, CS. 2014. Biomass production of energy willow under unfarouble field conditions. In Applied Ecology and Environmental research, vol. 12, 2014, no. 1, pp. 1-11. ISSN 15891623.

NÉMETH, J. 2010. Monitoring of the experimental stands of willow variety Express. Final report. Silvanus Faiskola, Kapuvár. 89 p.

PORVAZ, P. - TÓTH, Ś. 2013. Ekonomická efektivita pestovania Miscanthus $\times$ giganteus $v$ podmienkach východoslovenskej nižiny. In Zborník príspevkov z vedeckej konferencie Rýchloratsúce dreviny a byliny pestované na energetické účely $v$ podmienkach Slovenska. Nitra : SPU, 2013. ISBN 978-80-552-1098-8.

SO SR. 2013. Súpis plôch osiatych polnohospodárskymi plodinami k 20. 5. 2013. Bratislava: Ústredie Šú SR. ISBN 978-80-8121-265-9.

SSCRI. 2014. Pôdy pre pestovanie rýchlorastúcich drevín. [Retrieved 2014-11-27]. Retrieved from: http://www.podnemapy.sk/portal/ verejnost/rr_dreviny/rr_dreviny.aspx.

TRNKA, M. 2009. Experiences from growing of fast-growing woody crops in microregion Bystřice $\mathrm{U}$ P. In Proceedings from the scientific conference, 2009. $121 \mathrm{p}$.

van DAM, J. - FAAIJ, A. P. C. - LEWANDOWSKI, I. - FISCHER, G. 2007. Biomass production potentials in Central and Eastern Europe under different scenarios. In Biomass and Bioenergy, vol. 31, 2007, no. 6, pp. 345-366. ISSN 0961-9534. 